\title{
Peran VAM (Vesicular Arbuscular Mycorrhiza) terhadap Aktivitas Fotosintetik dan Produksi Osmoprotektan pada Tanaman Kedelai (Glycine Max L.) di Tanah Kering
}

\author{
L. Saidah, S. Nurhati, A. Muhibuddin \\ Faculty of Science, Sepuluh Nopember Institute of Technology, Faculty of Agriculture, Brawijaya University \\ e-mail :nurhatika@bio.its.ac.id
}

\begin{abstract}
Abstrak-Kedelai (Glycine max) merupakan tanaman yang membutuhkan air cukup banyak terutama pada stadium awal pertumbuhan, masa berbunga dan pembentukan serta pengisian polong. Pada umumnya kedelai di Indonesia ditanam pada lahan yang berpotensi mengalami keterbatasan air yang dapat menyebabkan terhambatnya pertumbahan tanaman karena selain menghambat proses fotosintesis juga dapat menghambat proses penyerapan hara dari dalam tanah oleh akar tanaman. Oleh karena itu dibutuhkan agen biologi untuk dapat membantu penyerapan hara yang dibutuhkan tanaman dalam kondisi tercekam dengan menggunakan mikoriza. Tujuan dari penelitian ini adalah dapat mengetahui pengaruh pemberian mikoriza vesikular arbuskular dengan dosis mikoriza sebanyak 2 gram, 4 gram, 6 gram, 8 gram, 10 gram, dan juga kontrol pada tanaman kedelai yang tercekam kekeringan dengan melakukan pengujian pada aktivitas fotosintetik, dan produksi osmoprotektan pada tanaman kedelai di tanah dengan kadar air rendah.Hasil yang didapat yakni pemberian mikoriza memberikan dampak terhadap beberapa parameter yang diuji seperti pada tinggi tanaman, luas daun, jumlah daun dan juga kadar prolin yakni memiliki $p$ value $<\mathbf{0 , 0 5}$.
\end{abstract}

Kata kunci-Cekaman kekeringan, Kedelai (Glycine max L), Mikoriza.

\section{PENDAHULUAN}

$\mathrm{C}$ EKAMAN kekeringan pada saat pengisian polong tanaman kedelai akan berdampak pada produksi yang rendah karena biji yang dihasilkan lebih kecil, mempercepat gugurnya daun, dan memperpendek periode pengisian polong [1]. Cekaman kekeringan pada fase vegetatif menyebabkan diameter batang mengecil, lebih pendek, stomata menutup dan bobot kering berkurang. Cekaman kekeringan pada saat proses pembentukan bunga akan mengurangi jumlah bunga yang terbentuk sehingga jumlah polong akan berkurang secara nyata [2]. Cekaman kekeringan juga menyebabkan terhambatnya pertumbahan tanaman, karena menghambat fotosintesis dan penyerapan hara dari dalam tanah. Cekaman kekeringan dapat terjadi pada kondisi $<60 \%$ kapasitas lapang [2].

Cekaman kekeringan selama ini diatasi dengan pemanfaatan mikroba, seperti mikoriza. Mikoriza adalah agen hayati yang bermanfaat untuk membantu penyerapan air dan juga unsur hara. Selain itu, mikoriza biasa digunakan untuk meningkatkan ketahanan tanaman terhadap serangan patogen terutama patogen tular tanah. Mikoriza merupakan bentuk simbiosis mutualisme antara jamur dan akar tanaman tingkat tinggi yang menginfeksi akar inangnya [3].

Mikoriza yang telah menginfeksi akar tanaman inang akan memproduksi jalinan hifa secara intensif dan memperpanjang hifa tersebut sehingga tanaman yang mengandung mikoriza mampu meningkatkan kapasitas dalam penyerapan hara baik unsur hara maro maupun mikro, dan juga air [1]. Fungi mikoriza ini pada umumnya dapat ditemukan pada spesies tanaman tingkat tinggi yang tumbuh pada berbagai tipe habitat dan iklim. Adapun penyebarannya bervariasi menurut iklim, lingkungan dan tipe penggunaan lahan [4]. Mikoriza indigenous berpotensi besar sebagai pupuk hayati (biofertilizer) karena salah satu sumber mikroorganisme tanah yang sangat membantu di dalam siklus unsur hara, yaitu dengan memfasilitasi penyerapan hara dalam tanah sehingga dapat meningkatkan pertumbuhan tanaman. Akan tetapi adakalanya asosiasi mikoriza tidak selalu menguntungkan tanaman inangnya tergantung pada faktor lingkungan seperti suhu, $\mathrm{pH}$ tanah, kelembapan tanah, kandungan fosfor, nitrogen dan kalium [4].

Berdasarkan kondisi tersebut, dapat dilakukan pengembangan mengenai peranan mikoriza dalam membantu penyerapan hara pada tanaman yang tercekam kekeringan dengan melakukan penelitian mengenai peranan Vesicular Arbuscular Mycorrhiza (VAM) terhadap aktivitas fotosintetik tanaman kedelai yang tercekam kekeringan, baik itu pada respon morfologis, fisiologis maupun biokimia tanaman kedelai. Hasil penelitian ini diharapkan dapat meningkatkan serapan hara dan juga air tanaman yang tercekam kekeringan sehingga dapat membantu pertumbuhan tanaman yang tercekam.

\section{METODOLOGI}

\section{A. Waktu dan Tempat}

Penelitian ini dilakukan pada bulan Januari 2018 sampai dengan Juni 2018 di green house urban farming ITS, Laboratorium Biosains dan Teknologi Tumbuhan Departemen 
Biologi Fakultas Ilmu Alam Institut Teknologi Sepuluh Nopember Surabaya, Laboratorium Zoologi dan Rekayasa Hewan Departemen Biologi Fakultas Ilmu Alam Institut Teknologi Sepuluh Nopember Surabaya dan Laboratorium Tanah Fakultas Pertanian Universitas Brawijaya, Malang.

\section{B. Alat dan Bahan}

Alat yang digunakan pada penelitian ini adalah Neraca analitik, polybag, nampan, sekop kecil, ember, benang, penggaris, spektrofotometer UV Vis, mortar dan pestel, kertas saring, oven, tabung reaksi, vortex, mikroskop stereo, isolasi, gelas objek, pisau, saringan bertingkat dengan pori 600, 180, 75, 63 dan $38 \mu \mathrm{m}$, cawan petri, mikro pipet.

Bahan yang digunakan pada penelitian ini adalah benih kedelai varietas dering1, tanah, formalin $5 \% 250 \mathrm{ml}$, pupuk mikoriza dari Fakultas Pertanian Universitas Brawijaya dengan kerapatann spora 21 spora per gram, kutex bening, kertas label, kertas, akuades $1.5 \mathrm{~L}$, alkohol $96 \% 10 \mathrm{ml}$, larutan sulfosalisilat $3 \% 10 \mathrm{ml}$, ninhidrin $1,2 \mathrm{gr}$, asam asetat glasial 30 $\mathrm{ml}$, asam fosfat $6 \mathrm{M} 20 \mathrm{ml}, 4 \mathrm{ml}$ toluen, ethanol $0,05 \mathrm{mM} 300$ $\mu \mathrm{l}$, ethanol 96\% 2,7 ml, dan larutan glukosa.

\section{Cara Kerja}

\section{1) Analisis Sifat Fisik dan Kimia Tanah}

Analisis sifat fisik dan kimia tanah dilakukan di Jurusan Tanah Fakultas Pertanian Universitas Brawijaya, Malang. Sampel tanah yang dianalisis merupakan sample tanah yang berasal dari tanah taman. Sample tanah tersebut dianalisis sebanyak 3 kali ulangan, masing-masing ulangan sebanyak \pm 250 gram. Sifat Fisik tanah yang diukur adalah tekstur tanah, pH tanah, dan suhu tanah. Sedangkan sifat kimia tanah yang diukur adalah bahan organik (C-organik), kandungan NPK, dan kadar air [5].

2) Persiapan Biji

Bahan yang digunakan meliputi akuades dan biji kedelai varietas dering1 yang diperoleh dari Balai Penelitian Tanaman Kacang-kacangan dan Umbi-umbian (BALITKABI), Kendal Payak-Malang.

Langkah yang dilakukan adalah biji kedelai varietas dering1 direndam selama 6 jam menggunakan akuades kemudian ditiriskan. Hal ini bertujuan untuk membantu proses imbibisi pada biji dimana perendaman tersebut dapat melembabkan kulit benih dan pori-porinya akan membesar dan air masuk ke bagian

3) Perlakuan Kering

Perlakuan kering yang diberikan pada penelitian ini adalah dilakukan penyiraman lima hari sekali dengan kadar air 50\% dari kapasitas lapang.

Parameter aktifitas fotosintetik yang di amati :

\section{Tinggi tanaman}

Pengukuran tinggi tanaman dilakukan dengan menggunakan benang dan penggaris dari atas permukaan tanah hingga ujung daun tertinggi yaitu pada bagian dimana daun terakhir tumbuh. Pengukuran tinggi tanaman dilakukan setiap 2 minggu sekali selama masa pertumbuhan [6].

\section{Jumlah daun}

Jumlah daun dihitung pada akhir perlakuan dengan menghitung jumlah keseluruhan daun pada setiap tanaman selain daun yang masih kuncup [6].

3. Luas daun

Pengukuran luas daun tanaman dilakukan dengan cara daun tanaman dipotong dan dipisah dari batangnya, kemudian dilakukan pengukuran menggunakan metode replika daun (blue print), yakni sebagai berikut : [7]

Luas daun $=\frac{\text { Berat Polax Luas Kertas }\left(\mathrm{cm}^{2}\right)}{\text { Berat Kertas }}$

Keterangan :

Berat Pola : Kertas yang sudah dibuat pola

Berat Kertas : Berat kertas yang belum digambar

Luas Kertas : Kertas yang pertama kali digunakan

\section{Kandungan Osmoprotektan Prolin}

Analisis produksi osmoprotektan dilakukan dengan mengukur kadar akumulasi prolin pada tanaman kedelai. Prolin dianalisis dengan cara daun segar sebanyak 0,5 gr ditimbang dengan timbangan analitik dan ditumbuk dalam mortar yang diberi larutan sulfosalisilat $3 \% \quad \mathrm{~b} / \mathrm{v}$ yang sebelumnya telah didinginkan dalam lemari pendingin. sebanyak $10 \mathrm{ml}$ selanjutnya filtrat disentrifuse selama 5 menit. Supernatan disentrifuse kembali hingga warna menjadi bening. Filtrat ditera hingga $10 \mathrm{ml}$, dan sebanyak $2 \mathrm{ml}$ dari filtrat yang diperoleh, direaksikan dengan $2 \mathrm{ml}$ ninhidrin asam $(1.2 \mathrm{~g}$ ninhidrin dalam $30 \mathrm{ml}$ asam asetat glasial dan $20 \mathrm{ml} 6 \mathrm{M}$ asam fosfat). Ninhidrin dalam $30 \mathrm{ml}$ asam direaksikan 24 jam sebelum analisis dilakukan. Filtrat kemudian dipanaskan pada suhu $100 \mathrm{oC}$ selama $1 \mathrm{jam}$, dan reaksi diakhiri dalam bak berisi air es. Campuran reaksi diekstraksi dengan $4 \mathrm{ml}$ toluene, diaduk dengan vorteks selama 15-20 detik. Kromofor yang mengandung toluene dikeluarkan dari fase air, dihangatkan pada suhu kamar dan absorban diukur pada panjang gelombang $520 \mathrm{~nm}$. Toluene digunakan sebagai blangko. Konsentrasi prolin ditentukan dengan kurva standar prolin [8].

\section{HASIL DAN PEMBAHASAN}

\section{A. Tinggi Tanaman}

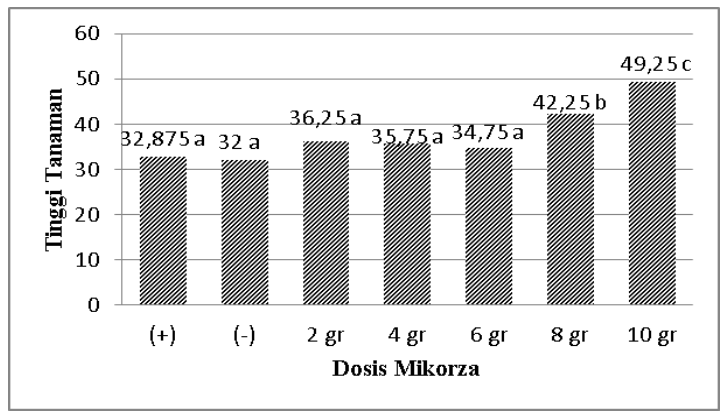

Gambar 1. Diagram rata-rata pertumbuhan tinggi tanaman kedelai (G. max L.) 
Hasil tinggi tanaman memiliki $p$ value $<0,05$ yang menunjukkan bahwa pemberian mikoriza pada tanaman kedelai yang diberikan perlakuan kekeringan berpengaruh terhadap pertumbuhan tinggi tanaman kedelai. Dapat dilihat pada gambar 1 dan tabel 11 bahwa tanaman kedelai pada konsentasi 8 gr dan 10 gr berbeda nyata dengan dosis mikoriza yang lebih rendah dan juga kontrol, baik pada kontrol positif maupun negatif, berkaitan dengan perlakuan pemberian mikoriza yang dapat membantu tanaman dalam cekaman kekeringan yang diberikan baik dalam penyerapan hara maupun air. Hal tersebut didukung dengan pernyataan [9] bahwa peningkatan pertumbuhan tanaman kedelai pada kondisi cekaman air disebabkan terjadinya infeksi akar oleh mikoriza terhadap tanaman kedelai, sehingga akar yang terinfeksi oleh mikoriza ini mampu meningkatkan penyerapan unsur hara $\mathrm{N}$ dan air di dalam tanah unsur hara $\mathrm{N}$ dapat membantu tanaman dalam pertumbuhan. Mikoriza tidak hanya membantu tanaman dalam penyerapan unsur hara dan air, tetapi juga dapat menghasilkan hormon dan zat pengatur tumbuh seperti auksin, gibrelin dan sitokinin. Auksin dapat mempercepat pembentukan dan perpanjangan batang serta daun, berperan dalam perpanjangan dan pertumbuhan awal akar, meningkatkan permeabilitas sel terhadap air dan pengembangan dinding sel [9][10]Sedangkan gibrelin tidak hanya merangsang pemanjangan batang, tetapi juga pertumbuhan tanaman secara keseluruhan, termasuk akar dan daun [11].

\section{B. Luas Daun}

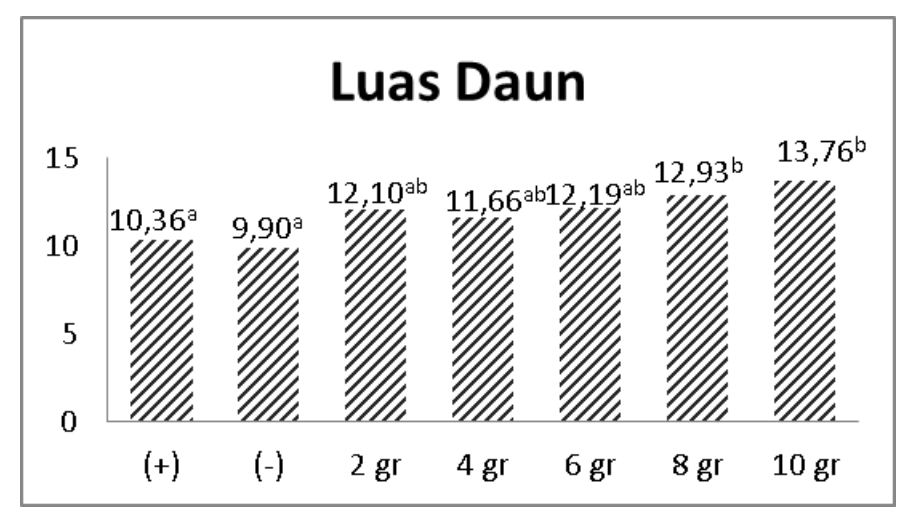

Gambar 2. Diagram hasil luas daun pada tanaman kedelai (G. max L.)

Hasil uji ANOVA pada luas daun memiliki $p$ value $<0,05$ Sehingga menunjukkan bahwa dosis mikoriza yang diberikan pada tanaman dalam kondisi kekeringan berpengaruh nyata terhadap luas daun tanaman kedelai. Berdasarkan gambar .2 dapat diketahui bahwa pada perlakuan mikoriza dengan dosis 8 gr dan 10 gr berbeda nyata dengan perlakuan kontrol positif dan negatif sehingga dapat ditarik kesimpulan bahwa dengan penambahan mikoriza sebanyak 8 gr dan 10 gr dapat membantu tanaman kedelai dalam kondisi kekeringan yang ditunjukkan pada respon fisik berupa luas daun tanaman.

Tanaman akan merespon kekurangan air dengan mengurangi laju transpirasi untuk penghematan air. Kekurangan air pada daun akan menyebabkan sel-sel tanaman kehilangan turgor. Mekanise yang dapat memperlambat laju transpirasi salah satunya adalah dengan memperkecil luas permukaan daun dari ukuran normalnya. Memperkecil luas permukaan daun juga akan memperkecil tangkapan radiasi surya sehigga berdampak terhadap penurunan volume fotosintesis [12] [13] [12] juga menyatakan bahwa respon tercepat pada pada cekaman kekeringan ditandai dengan keadaan fisik dari tumbuhan daripada perubahan kimianya.

Jika dilihat dari hasil (gambar 2) diketahui bahwa tanaman kedelai tanpa mikoriza (kontrol) memiliki luas daun yang kecil sehingga dapat disimpulkan bahwa tanaman tersebut sedang merespon kekurangan air yang terjadi. Berbeda dengan tanaman kedelai yang diberi mikoriza 8 gr dan 10 gr memiliki luas daun yang lebih besar dibandingkan dengan tanaman kedelai pada dosis mikoriza yang lebih rendah maupun kontrol. Hal tersebut membuktikan bahwa tanaman kedelai dengan dosis mikoriza $10 \mathrm{gr}$ dapat membantu dalam mengatasi cekaman kekeringan. Sebagaimana yang telah dinyatakan oleh [14] bahwa mikoriza dapat memperluas bidang serapan air dan hara pada tanaman. Unsur hara dan air yang diserap tanaman akan digunakan dalam proses metabolisme tanaman, khususnya meningkatkan proses fotosintesis sehingga fotosintat yang dihasilkan sebagian ditranslokasikan untuk pertambahan luas daun. [11] mengemukakan bahwa perkembangan dan peningkatan ukuran daun dipengaruhi oleh ketersediaan air dan unsur hara. Hal ini dikarenakan air dan unsur hara yang terlarut akan diangkut ke bagian atas tanaman dan sebagian lagi akan digunakan untuk meningkatkan tekanan turgor sel daun [15][16]menyatakan bahwa unsur hara $\mathrm{N}$ merupakan unsur hara yang berperan dalam merangsang pertumbuhan vegetatif seperti merangsang pertumbuhan daun pada tanaman.

\section{Jumlah Daun}

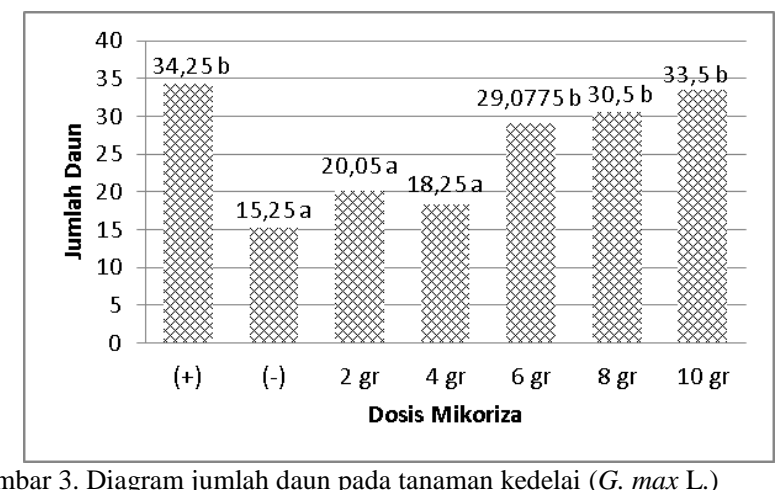

Berdasarkan hasil uji analisis ANOVA, rata-rata jumlah daun memilki nilai signifikansi $<0,05$. Sehingga menunjukkan bahwa dosis mikoriza yang diberikan pada tanaman dalam kondisi kekeringan berpengaruh nyata terhadap jumlah daun pada tanaman kedelai. Dilihat dari gambar 3 tanaman kedelai pada dosis 6 gr, 8 gr, 10 gr dan juga kontrol positif berbeda nyata dan juga memiliki jumlah daun yang tinggi yakni 6 gr $(29,08), 8$ gr $(30,50), 10$ gr $(33,50)$ dan kontrol positif $(34,25)$ jika dibandingkan dengan perlakuan dengan pemberian mikoriza 2 gr, 4 gr dan juga kontrol negatif. Hal tersebut 
disebabkan karena pada dosis mikoriza 2 gr, 4 gr dan kontrol negatif tercekam kekeringan sehingga tanaman menggurkan daunnya untuk bisa mengurangi proses transpirasi yang terjadi. Menurut [17] semakin besar tekanan cekaman air maka semakin besar pula nilai intensitas kerusakan daun yang merusak kloroplas sehingga daun akan cepat mengalami klorosis. Jumlah daun yang sedikit pada saat cekaman kekeringan juga disebabkan oleh adanya gangguan pertumbuhan serta mekanisme adaptasi tanaman melalui pengguguran daun untuk mengurangi kehilangan air dalam jumlah yang besar.

Sedangkan pada tanaman dengan dosis mikoriza dosis $6 \mathrm{gr}$, $8 \mathrm{gr}$, dan 10 gr jumlah daun tidak mengalami penurunan yang disebabkan adanya simbiosis dengan mikoriza sehingga tanaman dapat menyerap tetap menyerap unsur hara meskipun dalam kondisi tercekam, karena mikoriza yang telah menginfeksi akar tanaman tersebut akan memanjangkan hifanya untuk dapat menyerap unsur hara yang tersedia dalam tanah, sedang pada tanaman kontrol positif memiliki jumlah daun yang tinggi dikarenakan pada tanaman kedelai tersebut tidak mengalami kekeringan. Hal tersebut didukung dengan pernyataan [14] bahwa jumlah daun erat hubungannya dengan kemampuan tanaman dalam memanfaatkan unsur hara yang tersedia dalam melakukan proses fotosintesis guna mendapatkan nutrisi dan sumber makanan. Tanaman memanfaatkan unsur hara yang ada sebagai pendukung untuk melakukan proses fotosintesis sebagai sumber karbon. Dari pernyataan [14] tersebut, dapat ditarik kesimpulan bahwa tanaman pada dosis mikoriza 6 gr, 8 gr, 10 gr dan kontrol positif memiliki unsur hara yang cukup atau mampu memanfaat kan unsur hara yang tersedia jika dibandingkan dengan tanaman kedelai tanpa mikoriza (kontrol) ataupun tanaman kedelai yang memiliki dosis mikoriza lebih rendah [5] menyatakan bahwa ketersediaan unsur hara $\mathrm{N}$ dapat membantu dalam pembentukan sel daun.

Selain unsur $\mathrm{N}$, mikoriza juga membantu dalam penyerapan unsur hara $\mathrm{K}$ atau kalium dimana unsur hara tersebut juga berpengaruh terhadap jumlah daun [18]. menyatakan bahwa semakin tinggi unsur $\mathrm{K}$ maka semakin banyak pula jumlah daun yang dihasilkan, karena unsur $\mathrm{K}$ berperan penting dalam fotosintesis, dan secara langsung meningkatkan pengambilan karbondioksida $(\mathrm{CO} 2)$.

\section{Produksi Osmoprotektan}

Pada pengamatan produksi osmoprotektan dilakukan uji kadar asam amino prolin pada tanaman dikarenakan merupakan indikator cekaman kekeringan yang banyak digunakan. [8] menyebutkan bahwa pengingkatan kadar prolin meningkat dibandingkan asam amino lainnya. Hasil kadar prolin yang diperoleh akan di dibandingkan dengan kurva standart yang telah dibuat menggunakan prolin murni sebelumnya. Berikut hasil yang di dapat :
Tabel 1.

Prolin Murni

\begin{tabular}{lcc}
\hline \hline No & Konsentrasi & Absorbansi $520 \mathrm{~nm}$ \\
\hline 1. & $12 \mathrm{ppm}$ & 0,243 \\
2. & $14 \mathrm{ppm}$ & 0,287 \\
3. & $16 \mathrm{ppm}$ & 0,296 \\
4. & $18 \mathrm{ppm}$ & 0,328 \\
5. & $20 \mathrm{ppm}$ & 0,401 \\
\hline \hline
\end{tabular}

Berdasarkan data hasil uji menggunakan prolin murni diatas, maka dibuat kurva standar dengan sumbu x merupakan konsentrasi prolin per ppm dan sumbu y merupakan nilai absorbansi ada $520 \mathrm{~nm}$. Sehingga dapat dibuat grafik sebagai berikut :

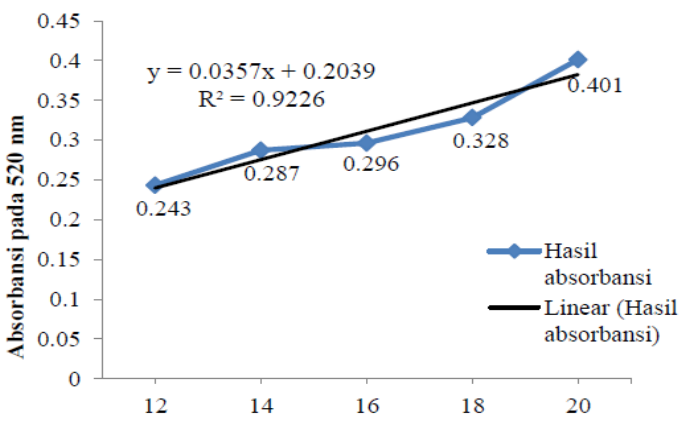

Gambar 4. Grafik kurva standar prolin

Dari persamaan kurva sandart prolin didapat nilai $\mathrm{y}=$ $0,0357 x+0,2039$ dan akan dihitung konsentrasi prolin (ppm) pada daun tanaman kedelai yang telah diberikan perlakuan pemberian mikoriza dengan berbagai dosis dan juga pada kontrol yakni tanpa mikoriza. Berikut merupakan hasil kandungan prolin yang didapat :

Tabel 2.

Nilai kadar prolin pada tanaman kedelai $(\mu \mathrm{mol} / \mathrm{prolin} / \mathrm{gr})$

\begin{tabular}{ccccc} 
No. & $\begin{array}{c}\text { Perlakuan } \\
\text { sample }\end{array}$ & $\begin{array}{c}\text { Absorbansi } \\
520 \mathrm{~nm}\end{array}$ & $\begin{array}{c}\text { Prolin } \\
(\mathrm{ppm})\end{array}$ & $\begin{array}{c}\text { Kadar prolin pada } \\
\text { daun segar }(\mu \mathrm{mol} / \\
\text { prolin/gr })\end{array}$ \\
\hline 1 & $(+)$ & 3,106 & 81,291 & 28,208 \\
2 & $(-)$ & 4,684 & 125,49 & 43,546 \\
3 & $2 \mathrm{gr}$ & 4,121 & 109,72 & 38,074 \\
4 & $4 \mathrm{gr}$ & 4,361 & 116,45 & 40,406 \\
5 & $6 \mathrm{gr}$ & 1,07 & 24,26 & 8,418 \\
6 & $8 \mathrm{gr}$ & 3,002 & 78,38 & 27,197 \\
7 & $10 \mathrm{gr}$ & 2,656 & 68,69 & 23,833 \\
\hline
\end{tabular}




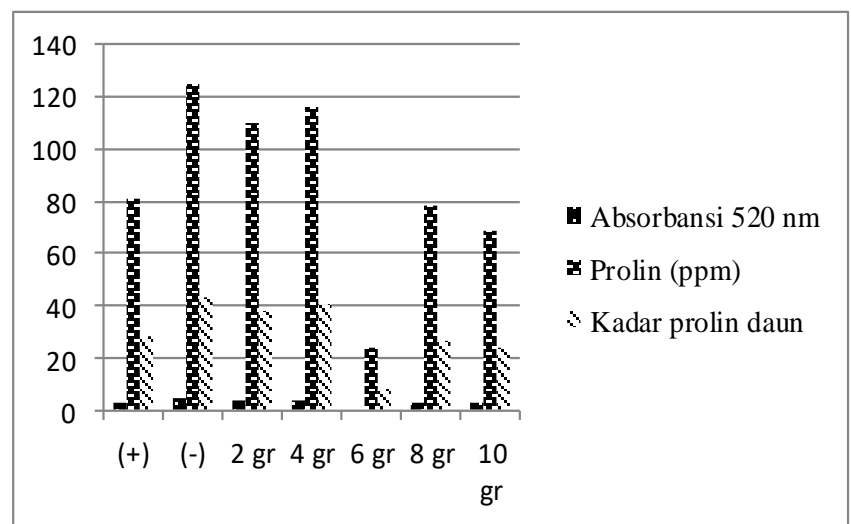

Gambar 5. Diagram nilai absorbansi $520 \mathrm{~nm}$, prolin (ppm), dan kadar prolin pada daun segar ( $\mu \mathrm{mol} /$ prolin/gr)

Hasil uji ANOVA one-way memiliki $p$ value $<0,05$ sehingga menunjukkan bahwa perlakuan pemberian mikoriza secara signifikan berpengaruh terhadap kandungan prolin tanaman kedelai. Dimana dapat dilihat pada gambar 5 bahwa tanaman kedelai pada kontrol negatif memiliki nilai kadar prolin pada daun yang paling tinggi dari yang lain, yakni 43,546. Hal tersebut adalah dampak dari perlakuan kekeringan yang diberikan yang didukung oleh pernyataan [19] yang menyatakan bahwa tanaman yang tercekam kekeringan akan mengalami peningkatan kadar prolin dan prolin tersebut akan melindungi membaran dan protein terhadap tingginya konsentrasi ion-ion organik da juga suhu ekstrim [20] juga menyebutkan bahwa prolin yang disintesis selama periode kekurangan air dapat berperan sebagai penyedia nitrogen organik yang berguna pada proses pemulihan sel. Sebaliknya pada perlakuan pemberian mikoriza 6 gr memiliki nilai prolin yang paling rendah yakni 8,418 dimana [19] menyatakan bahwa simbiosis antara akar tanaman tingkat tinggi dengan mikoriza dapat menyebabkan tanaman yang berada pada cekaman kekeringan akan beradaptasi terhadap kekurangan air tersebut yang disebabkan akar tanaman bermikoriza dapat melakukan penyebaran hifa secara luas untuk membantu dalam penyerapan air sehingga tanaman dapat tumbuh dengan normal.

Setelah dilakukan uji lanjut Duncan, diketahui bahwa pada tanaman dengan dosis mikoriza 6 gr tidak berbeda nyata dengan kontrol positif. Hal tersebut dapat dikaitkan dengan parameter tinggi tanaman dan juga berat kering tanaman dimana pada dosis-dosis tersebut memiliki nilai yang lebih tinggi dari pada tanaman dengan dosis mikoriza 6 gr (gambar 2 dan gambar 3). Hal tersebut juga dapat dikarenakan tanaman pada dosis mikoriza memiliki respon terhadap cekaman kekeringan yang berbeda-beda yakni pada tanaman dengan dosis mikoriza 6 gr merespon adanya cekaman kekeringan pada sintesis biokimia pada tanaman, akan tetapi mengalami penurunan terhadap respon morfologis yang di hasilkan, sedangkan sebaliknya yang terjadi pada tanaman dengan dosis 2 gr, 4 gr, 8 gr, dan 10 gr dimana pada kondisi kekeringan tanaman tersebut tidak mengalami penurunan pada parameter morfologi dan juga tingkat produktifitas yakni biomassa tanaman yang tetap tidak mengalami penurunan, tetapi pada sintesis biokimia prolin mengalami kenaikan yang mengindikasikan bahwa tanaman tersebut tercekam. Hal tersebut didukung dengan pernyataan Novenda dan Setyo (2016) yang menyatakan bahwa cekaman kekeringan yang terjadi pada tanaman menyebabkan beberapa dampak diantaranya yakni penurunan aktivitas metabolisme primer, dan aktivitas fotosintesis dimana dampak yang terjadi tersebut dipengaruhi oleh tanggapan masing-masing jenis tanaman.

\section{KESIMPULAN}

Kesimpulan pada penelitian ini adalah pada tinggi tanaman, luas daun, jumlah daun dan juga kadar prolin pada tanaman kedelai berpengarh nyata terhadap perlakuan yang diberikan yakni memiliki $p$ value $<0,05$.

\section{DAFTAR PUSTAKA}

[1] W. Muis, A., Didik, I., dan Jaka, "Pengaruh Inokulasi Mikoriza Arbuskula terhadap Pertumbuhan dan Hasil Kedelai (Glycine Max (L.) Merrill) pada Berbagai Interval Penyiraman," Vegetalika, vol. 2, no. 2, 2013.

[2] W. Suryanti, S., Didik, I., Putu, S., and Jaka, "Kebutuhan Air, Efisiensi Penggunaan Air an Ketahanan Kekerigan Kultivar Kedelai," Agritech, vol. 35, no. 1, 2015.

[3] Y. Setiadi, "Pemanfaatan Mikroorganisme Dalam Kehutanan," 2001.

[4] E. A. Pang, P. C., and Paul, "Effect Of MVA On 14C And 15N Distribution In Nodulated Fababeans," J. Soil, vol. 60, pp. 241249, 1980.

[5] A. Nugroho, T.C., Oksana, dan Ervina, "Analisis Sifat Kimia Tanah Gambut yang Dikonversi Menjadi Perkebunan Kelapa Sawit di Kabupaten Kampar,” J. Agroteknologi, vol. 4, no. 1, 2013.

[6] L. Pauline, D.K., Sunarti, C. dan Ilmiati, "Pemanfaatan Mulsa Serbuk Gergaji Untuk Mengatasi Pengaruh Cekaman Kekeringan pada Bibit Tanaman Cabai (Capsicum annuum L.)," J. Din., vol. 8, no. 1, pp. 30-40, 2017

[7] dan B. G. Sitompul, S.M., Analisis Pertumbuhan Tanaman. Yogyakarta: UGM Press, 2017.

[8] D. . Khaerana, Munif, G., dan Edi, "Effect of Drought Stress and Harvesting Time on Plant Growth and Xanthorrhizol Content of Curcuma xanthorrhiza Roxb," Bul.Agron, vol. 36, no. 3, 2008.

[9] A. Buhaira, Nerti, S., Ardiyaningsih, P.L., dan Yudhi, "Pertumbuhan dan Hasil Tanaman Kedelai dengan Pemberian Mikokompos dalam Kondisi Cekaman Air," J. Agroteknologi, vol. 2, no. 3, 2013.

[10] A. S. Parnata, Pupuk Organik Cair. Jakarta: PT. Agromedia Pustaka, 2004.

[11] B. Lakitan, Dasar-Dasar Fisiologi Tumbuhan. Jakarta: PT. Raja Grafindo Persada, 2004.

[12] D. . Moctava, M.A., Koesrihati, M., "Responses of Three Mustard Varieties (Brassica rapa L.) Towards Water Stress Environment," $J$. Produksi Tanam., vol. 1, no. 2, 2013.

[13] J. Sujinah, dan Ali, "Mekanisme Respon Tanaman Padi terhadap Cekaman Kekeringan dan Varietas Toleran," Iptek Tanam. Pangan, vol. 11, no. 1, 2016.

[14] D. . Lukitanigdyah, "Tingkat Persen Infeksi Propagul Mikoriza Vesikular Arbuskular Indigenous Asal Desa Pangpong Kec. Labang Kab. Bangkalan Madura pada Perakaran Tanaman Padi (Oryza Sativa), Kedelai (Glycine Max L.), Dan Tanaman Gulma Rumput Teki (Cyperus Rotundus)," Institut Teknologi Sepuluh Nopember, 2013.

[15] T. Suharno, I., Mawardi, Setiabudi, N., Lunga, S., "Efisiensi penggunaan nitrogen pada tipe vegetasi yang bereda di stasiun penelitian taman nasional gunung halimun Jawa Barat," Biodiversitas, vol. 8, pp. 287-294, 2007. 
[16] dan A. Daryadi, "Pengaruh Pemberian Kompos Ampas Tahu Dan Pupuk NPK terhadap Pertumbuhan Bibit Kakao (Theobroma cacao L.)," JOM FAPERTA, vol. 4, no. 2, 2017.

[17] R. dan M. A. Efendi, "Identifikasi Karakter Toleransi Cekaman Air Berdasarkan Respons Pertumbuhan dan Hasil Genotipe Jagung," $J$. Balai Penelit. Tanam. Serealia, 2008.

[18] E. Roesmayanti, "Pengaruh Kosenterasi Pupuk Pelengkap dan asam Giberelat (GA3) terhadap Pertumbuhan dan Hasil Terung Jepang ( Solanum Melongena L. ) secara Hidroponik," Universitas Sebelas Maret, 2004.

[19] A. . Novenda, I.K., dan Setyo, "Analisis Kandungan Prolin Tanaman Kangkung (Ipomoea reptana Poir), BayaM (Amaranthus spinosus), dan Ketimun (Cucumis sativus L.)," Pancaran, vol. 5, no. 4,2016

[20] D. . Lawlor, "Limitation of Photosynthesis in Water Stress Leaves : Stomata vs Metabolism and The Role of ATP," Ann Bot, vol. 89, pp. 871-885, 2002. 